\title{
Unlocking finance for social tech start-ups: is there a new opportunity space?
}

Marika Arena, Irene Bengo, Mario Calderini, Veronica Chiodo

Department of Management, Economics and Industrial Engineering , Politecnico di Milano

\begin{abstract}
This paper aims to perform a critical analysis of the financial instruments that can be employed for funding social innovation, with a specific focus on social tech start-ups that develop and deploy technology driven solutions to intentionally address a social need in a financially sustainable manner. The paper analyses how social tech start-ups can access to financing, what barriers do these organizations experience in looking for finance and what financial instruments are more suitable to answer to their financial needs. Social tech startups present many contact points with high tech start-ups concerning the barriers they encounter to financing in different lifecycle stages. Still, the institutional solutions that are commonly exploited by high tech startup to grow are not enough to support social tech start-ups to scale. Therefore we introduce the concept of Social impact investing (SII) and discuss its potential contribution to the social tech finance landscape. Then, we formulate a research agenda, identifying directions for research and theory development in the field of SIl using the case of social tech start-ups as paradigmatic of the broader problem of financing mechanisms for social innovation.
\end{abstract}

\section{Keywords}

social innovation, social tech start-ups, funding barriers, social impact investing, research agenda

\section{Introduction}

The debate about the emergence of new entrepreneurial genre, the social tech start-ups, is fuelled by an increasing number of examples of entrepreneurial initiatives that could easily defined either high tech startups or social enterprises, depending on the perspective that is used to investigate their multifaceted nature.

Pedius is a successful tech-intensive start-up that allows deaf or hard of hearing people to perform phone calls. Pedius business model is centred on a communication system based on speech recognition and synthesis technologies. Pedius' offer allows access to the service to anyone who needs it. It entails a free plan whereby each account is granted 20 minutes per month without paying any fee, and two tariff plans: a 5 euro fee for 100 minutes calls and a 30 euros yearly fee that covers unlimited calls (fees accessed 20 December 2016). The strategic positioning and pricing strategy reflects a business approach that is somehow mediated by a clear commitment to social impact objectives, that explicitly coexist with busness objectives. The hybridization of its mission and objectives has not prevented Pedius to perform in strictly speaking business terms. Pedius idea was conceived in 2012; after four years, in 2016, Pedius has become a business venture 
active in 9 countries, counting 8 full-time employees and 12.000 users. On top, Pedius has been able to attract the interest of investors, and received equity investments for over one million euros.

A second example tht is usually quoted when trying to give concrete account of successful hybrid social ventures is MarioWay, the upright revolution. MarioWay created an innovative type of wheelchair: it can be driven without using the hands, it is fully customisable to take into account the features of the user and it allows the user to assume a stading position. In so doing, this new tool provides both health and relational benefits to disable people. Indeed, allowing them to live their everyday life in a stading postion, it enhances their feeling of inclusion in the society. MarioWays was founded in 2013, and today it is ready the launch its innovative product in the market. In the 2015, the European Investment Bank has awarded Marioway as one of the best socially innovative ideas in Europe and it received a round of capital from business angels.

These are two examples, among many others, of a new generation of ventures: the social tech start-ups. It is still rather premature to consider such examples archetypes of a new entrepreneurial genre, but there are recurring features that are highly likely to become distinguishing features of the social tech start-ups model of entrepreneurship. One is certainly the carchteristic of new venture, that combined with technology (knowledge) intensity makes such initiatives very similar to the traditional definition of high-tech start-ups. The other one is hybridity, or blended-value mission, that is generated by the coexistence between social impact objectives and business ones.

Similarly, to high-tech start-ups, social tech start-ups are newly created organizations that are in the initial stages of their lifecycle and leverage technology to develop new products and services (Desa and Kotha, 2006; Kamariah, Mir and Umee, 2012). However, their distinctive feature, compared to other high tech startups, is that these ventures specifically aim to "develop and deploy technology driven solutions to address social needs in a financially sustainable manner" (Desa and Kotha, 2006). This feature - i.e. the twin cornerstone of intentionally addressing a social need and safeguarding a financial return - associate them to social enterprises (SES), that are commonly defined as those organizations that have primary social objectives, but seek to achieve them through forms of enterprise and trading (Austin, Stevenson and WeiSkillern, 2006; Haugh, 2007). SE's disruptive idea is the ability to generate a new business model that grounds in the provision of goods and / or services that answer to an unmet social need (Hynes, 2009).

Clearly distinguishing SEs from other organizations is challenging because SEs are hybrid entities that combine aspects of multiple organizational forms (Jay, 2013; Battilana and Lee, 2014). The term "social enterprise" has developed as an "umbrella" construct, "with a wide scope and ambiguous boundaries" (Battilana and Lee, 2014, p. 406), indicating a variety of arrangements characterised by the coexistence of a social and a business component. Hence, SEs can be positioned along a continuum between philanthropic and commercial organizations, and are not characterised by a unique legal form (Smith and Teasdale, 2012). 
Based on the EU commission data, there is a growing number of organizations that can be regarded as SEs: recent statistics report about 2 million enterprises active in the social economy (about the $10 \%$ of European enterprises). Focusing more specifically on Italy, according to the ISTAT census, there are more than 94.000 organizations that can be regarded as coherent with a broad SE definition, including social cooperatives, associations and foundations, and ex-lege social enterprises.

Against this landscape, social tech start-ups are gradually emerging as being characterised by the attempt of addressing different social needs by using advanced technology (Millard, and Carpenter, 2014). The diffusion of this peculiar type of new ventures has been favoured by two main trends. First, the need of dealing with social challenges has opened new market opportunities and the possibility of sizing these opportunities, exploiting potential synergies between technological and social innovation has been increasingly acknowledged (Bria, 2015). Second, policy makers have introduced some explicit incentives to support this type of new ventures, recognizing them a potential role in addressing relevant social issues (Misuraca Kucsera, Carretero, Bacigalupo, and Radescu, 2015).

Moving from the first issue, in the last twenty years, the worsening of the so called social challenges has made clear the need of rethinking the role that business and social organizations can play in the economic landscape (Haigh, Walker, Bacq and Kickul, 2015). Social needs represent a growing market that is being further enlarged by the welfare reduction. Companies and organizations operating in the social sector started to see opportunities for creating new business models and generate profits by addressing these social needs thanks to social innovation (Franz, Hochgerner and Howaldt, 2012; Grimm, Fox, Baines and Albertson, 2013; Cajaiba-Santana, 2014). Social innovation, in turn, increasingly leverages on technological innovation - i.e. exploiting technical and technological advancements to create products, artefacts, services or processes that can contribute to addressing a social problem (e.g. Gardner, Acharya and Yach, 2007; Rahman and Smit, 2014; Misuraca, Colombo, Kucsera, Carretero, Bacigalupo, and Radescu, 2015). From this perspective, social innovation is not only complementary to technological innovation - as it was initially conceived (Pot and Vaas, 2008) - but it brings technological innovation further, by fostering the establishment of a virtuous cycle whereby technological innovation becomes a relevant ingredient for enacting social innovation (Millard and Carpenter, 2014). Still the relationship between technological and social innovation is complex and difficult to disentangle (Grimm, et al., 2013) because the interplay between the technological domain and the social domain cannot be conceived as a one-way linear relationship.

The second factor that favoured the rise of social tech start-ups is related to the recognition of the relevance of this phenomenon by policy makers. In Europe, for instance, social innovation is claimed to be central in meeting the EU2020 targets to increase employment, improve education, reduce poverty and social exclusion and lower greenhouse gas emissions (European Commission 2012a, 2012b). These expectations are somehow transferred to SEs and social tech start-ups, as they are looked at as pivotal vehicles of social 
innovation (Alvord, Brown, and Letts, 2004). Something similar happened in the past in USA and in Western Europe (Battilana and Lee, 2014). In USA, during the 1980s non-profit organizations answered to a changed economic environment by developing new social projects able to mobilize alternative sources of funding. In Western Europe, in the 1970s social integration enterprises played a central role in a period of enduring unemployment to support unemployed and marginalized groups (Defourny and Nyssens, 2006; Kerlin, 2006).

These expectations are translated into different forms of support of which social tech start-ups can benefit. While the European Commission has expressed its interest in innovations that used thechnology to tackle social challenges by starting a mapping activity (see the projects "Digital Social Innovation for Europe" and "IESI Mapping Survey"), the Italian context provides an unique example of concrete support to transform social-tech ideas into entrepreneurial entity. In 2015, the Italian government has enacted a Legislative Decree for supporting innovative social start-ups - labelled in Italian "Start-up innovativa a vocazione sociale" (SIAV). This law sets specific requisites in terms of technological intensity and social mission that an organization should have in order to acquire the status of SIAV. On the technological side, a SIAV should prove the development, production and sale of high tech goods or services as core business and (1) deploying at least $15 \%$ of turnover or production costs to R\&D activity or (2) having at least one third of the employees with proven experience in scientific research or (3) owning at least one patent or intellectual property. On the social side, a SIAV should provide a self-certification of its social impact using a template set by the law and renounce to dividend distribution. Then, SIAVs benefit of relevant fiscal incentives, that are applied to individuals and companies that invest in these organizations. These incentives signal a specific willingness of the Government to support these organizations as a recognition that their activity has a potential of producing value for the community. At present the figures about the diffusion of SIAVs are still limited, but promising. In September 2016, 116 organizations registered as SIAVs: they include 105 limited lability companies or public companies and 11 social cooperatives, with a clear prevalence of the service sector (where operate 106 organizations out of 116). 61 organizations are newly created enterprises that have registered to the Register of the Chamber of Commerce in 2015.

Besides these enabling factors, the hybrid nature of social tech start-ups poses also some relevant challenges. The coexistence of social and commercial objectives, that is typical of any SE, requires these organizations to continuously face significant trade-offs, resulting in a higher level of complexity in establishing, leading and managing them (Alter, 2006; Austin et al., 2006; Leadbeater, 2007; Wilson and Post, 2013). In order to pursue their dual mission, they need to manage the demands of multiple stakeholder groups that are reflected in conflicting and competing, commercial and social logics (Battilana and Dorado 2010; Battilana Lee, Walker, and Dorsey, 2012). This leads to tensions arising from the relative prioritization of financial over social goals and influences their ability to mobilize resources (Doherty, Haugh and Lyon, 2014). 
In the case of social tech star-ups this challenge is further amplified because, technological advancement calls for the employment of considerable invested capital, leading to the need of identifying proper financing mechanisms.

So far, the public sector has played a significant role in financially sustaining SEs, thanks to its purchasing power (Allen, 2009; Heins, Price, Pollock, Miller, Mohan and Shaoul, 2010). However, the sovereign debt crisis has reduced the spending capacity of public administrations putting the organizations that operate in the social business sector under funding pressure. Several authors have therefore acknowledged that dependency on the public purse carries risks for the sustainability of the socially innovative sectors and funding streams have to be diversified to make SEs resilient and sustainable in cyclical environments (Grimm et al., 2013).

This dependency on public sector procurement is particularly evident in the Italian case. In 2011, revenues from public contracts amounted to $65 \%$ of the total income of social cooperatives, with only the $28 \%$ of revenues being generated from the sales of goods and services to private clients. In addition, if we analyse the funding composition of these organizations two dynamics can be highlighted. First Italian SEs still largely rely on their own financial resources. About $70 \%$ of these organisations finance themselves through contributions provided by members, surpluses resulting from business activities and grants (Venturi and Zandonai, 2012). More recently, they have increased their demand for commercial finance. In 2014, the volume of debt contracted by social cooperatives amounted to around EUR 7.9 billion (data processed by Euricse, drawing on the AIDA database) (Venturi and Zandonai, 2014).

Against the above background, we argue that there is considerable uncertainty as to how social tech startups can access to financing, what barriers do these organizations experience in looking for finance and what financial instruments are more suitable to answer to their financial needs. This issue has been largely unexplored in literature, even due to the novelty of the phenomenon from a business perspective. However, its analysis could share some theoretical underpinning with the literature concerning different forms of financing of high tech start-ups on the one hand and SEs on the other hand.

Hence, we first develop a critical analysis, discussing the main barriers that high-tech start-ups and social tech start-ups encounter in accessing to financing in different lifecycle stages, comparing institutional solutions through which they can finance their activities, and the specific features that make some options more suitable than other. We also introduce the concept of social impact investing (SII) and discuss its potential contribution to the social tech finance landscape. Then, we formulate a research agenda, identifying directions for research and theory development in the field of SII using the case of social tech start-ups as paradigmatic of the broader problem of financing mechanisms for social innovation. In doing so, we formulate some possible explanations for and critical analysis of an emerging phenomenon that is, as yet, under-theorized. 


\section{Financing social tech start-ups: barriers, institutional and emerging solutions}

In this section, we discuss the main problems that social tech start-ups encounter in accessing to finance and we outline the financial instruments that are available to these ventures, with reference to both traditional and emerging institutional solutions. In so doing, we enucleate the factors that make some institutional solutions more or less suitable to accomplish the objectives of a social tech start-up, considering the intentional pursuit of a social mission instead of profit maximisation.

To guide the analysis of the financing instruments, we refer to the seminal paper of Berger and Udell (1998) and more recent papers developed consistently with this framework (Carpenter and Petersen, 2002; Cassar, 2004; Mann and Sager, 2007; Colombo and Grilli, 2007). More specifically, we move from prior research about high tech ventures, that explores how the relationship between funding requirements and obstacles / barriers they meet varies across different lifecycle stages (Gompers and Lerner, 2001; Berger and Udell, 2002; Colombo and Grilli, 2010). As the lifecycle of social tech ventures shares many similarities with that of other enterprises (Nicholls and Pharoah, 2008; Burkett, 2010) we articulate the discussion around the typical stages of seed, start-ups, early growth, growth (Burkett, 2010; Cusumano, and Spano, 2012; Jacockes and Price, 2010). Using the findings concerning high tech ventures as a baseline, we outline the barriers that social tech start-ups encounter to access to financing in different lifecycle stages and the relationship with different financial instruments available, paying particular attention to and those factors that make some financing alternatives more / less suitable in different phases of the start-up lifecycle. Given the objective of this paper, specific attention will be given to the first two stages of the lifecycle, whilst the other stages will be just briefly revised for the sake of completeness. In so doing, we try to draw a prioritization of the financial sources in terms of ability to respond to social tech start-up's financial needs, but we do not mean that the different sources are mutually exclusive of a specific phase.

The first lifecycle stage is seed, when the innovative idea is conceived. In this phase, both the volume of sales of a new venture and its capital intensity is equal to zero (Jeng and Wells, 2000; Kortum and Lerner, 2000; Venturelli and Gualandri, 2009), the financial needs often consist just in the expenditure required to make a technical and economic assessment of the investment plan. In this phase, the main barriers that hamper access to finance for high tech ventures are their risk profile, that is even higher compared to later-stage entities (Ou and Haynes, 2006), and the fear of entrepreneurs to lose control over their own business idea (Howorth, 2001).

Compared to traditional high tech start-ups, social tech start-ups are perceived to be even riskier by potential investors (Bank of England, 2003; Howard and Giddens, 2004; Fraser, 2007). The aim of addressing a social problem often leads social tech start-ups to operate in sectors with higher failure rates and the perceived risk cannot be balanced by a corresponding financial prospect return (Martin, 2011; Nicholls, Emerson and 
Paton, 2015) since the hybrid mission of social ventures usually does not allow them to charge market prices or target customers with the highest purchasing power for their products and services (Karaphillis, Asimakos and Moore, 2010). Thus, social tech start-ups might not be able to generate a level of income that meets investors' return expectations (Kickul and Lyons , 2015). In addition, surpluses are often not used to provide a direct return on share capital leading to an unfavourable risk-return relationship. These barriers can make social tech start-ups unattractive for business angels, in this phase, and venture capital operators in the later stages.

Also, the problem of entrepreneurs fearing to lose control over their own idea is intensified by the presence of a social mission (Emerson, Freundlich, Fruchterman, Berlin and Stevenson, 2007; Nicholls and Pharoah, 2008; Ridley-Duff and Bull, 2011; Seddon, Hazenberg and Denny, 2013; Achleitner, Spiess-Knafl and Volk, 2014). Entrepreneurs in social tech start-ups might be more reluctant to give up some control over the management of the company due to the threat of mission drift (i.e. the focus on financial goals overtake that on social goals). Equity investors are typically profit seekers and they might not be aligned with the system of values that is inherent in a social venture, undermining the social mission.

In addition, compared to tech start-ups, a further barrier can be represented by the legal form of social tech start-ups. High tech start- ups in seed phase are predominantly supported by the financing of the founder itself (or the funds of family and friends) (Papadimitriou and Mourdoukoutas, 2002; Graham, Merges, Samuelson and Sichelman, 2009; Conti, Thursby, and Rothaermel, 2013). Nevertheless, this practice can be put off when the organization decides to assume a non-profit legal form since an entrepreneur might be reluctant to invest its savings without any ownership stake (Dees and Dolby, 1996; Jacokes and Pryce, 2010).

Because of these constraints, social tech ventures in the seed stage typically rely on grants and donations to finance their activities. Due to their social mission, they are usually highly embedded in the community, with strong relationships with different groups of stakeholders (Mair and Martì, 2006; Dacin, Dacin and Matear, 2010). Hence, their social mission becomes a source of legitimacy (Teasdale, 2010) which allows to obtain preferential terms from traditional grant makers such as philanthropic foundations, corporations and government agencies and attract new funding from individuals either through high net worth individuals $\left(\mathrm{HNWI}^{1}\right)$ and grass roots campaigns (Dees and Dolby, 1996; Dees, 1998). From this perspective, ICT technologies have heavily changed the donation marketing performed by social ventures (Lehner and Nicholls, 2014) and crowdfunding has emerged as a further financing opportunity to support seed and startups entities to raise capital beyond conventional sources. It basically consists in a new approach to gather small amounts of money from a large and diffuse audience, i.e. the crowd, leveraging on the Internet and social media platforms to achieve a global outreach (Colombo, Franzoni, and Rossi-Lamastra, 2015).

\footnotetext{
${ }^{1}$ According to the World Wealth Report 2016, HNWIs are defined as those having investable assets of US\$1 million or more, excluding primary residence, collectibles, consumables, and consumer durables.
} 
Crowdfunding can help social tech start-ups to bear the cost of proof-of-concepts and the first entrepreneurial steps somehow taking the place of FFF's funding (Lehner, 2013). Even in this case, social tech start-up can use the legitimacy of their mission to attract new actors: crowd investors are usually convinced by the core values and social goals of the ventures and they are less interested in collaterals or reliable business plan (Lehner and Nicholls, 2014). Crowdfunding can be considered a source of both grants, debt (lending crowdfunding or other peer to peer lending instruments) or equity capital.

Lastly, similarly to high tech start-ups (Phillips, 2002), a relevant role can be played by incubators; they contribute to the development of the social tech start-ups by supporting capacity building, in terms of managerial and financial expertise that are generally poorer in social ventures than in other for profit organizations (Conathy, 2001; Fraser, 2007; Lyon and Baldock, 2014; SEUK, 2015; Von Zedtwitz and Grimaldi, 2006).

In the second lifecycle stage, the start-up, the idea is presented to the market. In this stage, high tech ventures typically need considerable amounts of financing, due to the rising capital intensity, countered (at least initially) by a substantial absence of revenues (Hall and Woodward, 2010; Nanda and Rhodes-Kropf, 2013). This situation is worsen by the existence of significant information asymmetry between the entrepreneurs and possible external funders due to both the lack of trading history and the practical barriers to undertaking due diligence on new and unproven ventures (Cassar, 2004; Verheul and Thurik, 2001) and the confidentiality of data and information about start-ups projects (De Bettignies 2008). Information asymmetries are likely to increase the cost of raising external financing, as lenders seek higher interest rates and greater equity shares to compensate the risk of funding an unproven new venture (Harding, 2002; Watson and Wilson, 2002). Furthermore, this stage is characterized by both a moral hazard problem, i.e. entrepreneurs may behave opportunistically after obtaining external financing, and an adverse selection problem, i.e. the inability of investors to discriminate between start-ups with high quality projects from startups with bad quality projects (Colombo and Grilli, 2010). Finally, a last barrier consists in the absence of collaterals (Fielden, Davidson and Makin, 2000; Scellato, 2007), that is due to the intangible nature of most of high-tech investments. As a consequence, bank or other financial institutions are generally not willing to finance start-ups, because they hardly fulfill the criteria required to access to standard forms of debt (Cassar, 2004). On the other hand, being this stage less risky than the seed one, both business angels and venture capital firms are viable institutional solutions, though often venture capitalists invest in companies that have already received one or more rounds of angel finance (Shane and Cable, 2002; Cumming, Grilli, and Murtinu, 2014).

These barriers are amplified in the case of social tech ventures. First, the issue of information asymmetries is sharper in social tech start-ups since they do not fit neatly into either the traditional non-profit or for-profit model. Commercial investors are used to investing in traditional for-profit venture and may be less aware of 
the characteristics of social ventures, in particular those concerning their structure and governance (Fraser, 2007; Chertok, Hammoui, and Jamison, 2008). This may create a lack of understanding between organizations and potential investors. Since investors are less familiar or do not understand the business models that generate both social and financial return, they are very cautious in investing in social ventures (Bank of England, 2003; Achleitner et al., 2014). When they do so, they apply to these organizations the same requirements than those of for profit enterprises. In addition, due diligence and monitoring in the social sector is more difficult for various reasons (Burkett, 2010; Karaphillis et al., 2010; Martin, 2011; Desa and Basu, 2013). It is harder for social ventures to demonstrate their social impacts to potential funders due to absence of commonly recognised performance metrics measuring the social risk and return, and they often end up lacking the necessary track record (Kickul and Lyons , 2015; Nicholls et al., 2015; Bengo, Arena, Azzone and Calderini, 2016).

The issue of information asymmetry leads to a threat of moral hazard. Indeed, investors may be not sure whether or not the social venture will give primary importance on its social objectives, leaving aside the generation of income to repay them (Fraser, 2007).

Even though, like for high tech start-ups, equity funding provided by venture capital could be an option in this phase, social tech start-ups might experience another barrier: the legal form. Problems arise when it assumes a legal structure, typically pertaining to non-profit sector (Dees and Dolby, 1996), which imposes some non-distribution constraints or interest payment restrictions or entails a particular ownership structure (Austin et al., 2006; Mendell and Nogales, 2008; Jacokes and Pryce, 2010; Ridley-Duff and Bull, 2011). In this case, social tech start-ups are not attractive or less attractive for the investors with any form of financial returns expectations. On the other hand, the non-distributive restriction represents a protection for grant providers, resulting in a competitive advantage in the donations' market (Glaeser and Shleifer, 2001; Fischer, Wilsker, and Young, 2011; Fedele and Miniaci, 2010).

The combination of these challenges could lead to the problem of "grant dependency" (Conathy, 2001; Fraser, 2007; Sunley and Pinch, 2012; Seddon et al., 2013). In other words, organizations with a social mission can remain stuck in a charitable mind-set and be reluctant to take on commercial finance, especially when non-commercial sources of finance are familiar and readily available. This culture of grant dependency is problematic for two main motivations. First, commercial finance may be more appropriate in some instances than grant finance (Bank of England, 2003). For example, commercial finance can be used to finance longer term and broader goals than grant finance. Second, reliance on donations and government's grants make these organizations risky prospects for mainstream investors, leading to a vicious cycle (Karaphillis et al., 2010).

To deal with these problems, some new institutional solutions have emerged. 
The first family of instruments that has been put forth consists in the so called "hybrid capital" (Cusumano, and Spano, 2012; Spiess-Knafl, and Achleitner, 2012) - e.g. including, for instance, recoverable grants, convertible grants, forgivable loans, revenue share agreements (Nicholls and Pharoah, 2008; Spiess-Knafl, and Achleitner, 2012). These instruments move from those usually referred to as mezzanine financing, which combine elements of debt capital and equity capital, and they add a component related to donations. Hence, unlike traditional debt they are unsecured, like traditional equity they are somehow linked to the performance of a start-up, but they usually do not change the start-up's ownership structure; finally, they inherit the absence of interest from donations and that they can be converted into grants when certain conditions are realized. As a result, these financing forms are typically very flexible and can be structured and re-arranged according an organization's results.

A second family of mixed instruments is represented by "patient capital" including, for instance, long term grants with no exit strategies and low interest loans (Howard and Giddens, 2004; Jacokes and Pryce, 2010; Cusumano, and Spano, 2012; Haigh and Hoffman, 2012). The rationale underpinning these instruments is that the time horizon needed to tackle a social problem may not be aligned with the timelines of the potential commercial funders (Kickul and Lyons, 2015). Therefore, social economy organizations need a capital that is less commercial than equity capital, allowing less strict requirements on the repayment of the investment. Accordingly, patient capital's investors, indeed, usually set repayment conditions in order to follow the operations needed by the company to grow. These conditions usually entail a medium-term horizon, "repayment holydays", below market interest rate and they are often complemented with managerial support (Haigh and Hoffman, 2012).

Lastly, the role of traditional venture capitalist might be taken on by venture philanthropist (Lehner and Nicholls, 2014). Venture philanthropy is a new approach to grant making which uses the tools and criteria of venture funding (Daly, 2011; Hafenmayer, 2013; Moody, 2008). Thus, the aim of venture philanthropists is to maximize the positive social or environmental impact, but their approach inherit by the field of venture capital allows to enhance the growth of the business model of the enterprise. Moreover, according to Hafenmayer (2013) it shows the following features that might fit the needs of social tech start-ups: (a) extensive due diligence at the local level; (b) tailored forms of financing; (c) provision of support by means of intellectual and social capital to complement financial capital; (d) long-term commitment; (d) ongoing monitoring and performance measurement; (e) optimization of social and environmental returns.

In the third stage, early growth, a venture manufactures and markets its products, however, with some uncertainties about its actual profitability and the possibility that some changes to the initial idea, or additional investments, may be needed to expand the market (Ou and Haynes, 2006). Consequently, funding requirements grow larger compared to prior stages, but in parallel some of the prior barriers become less relevant (e.g. information asymmetry, intangibility of assets, lack of trading history, adverse selection...) 
(Cassar, 2004). In this stage, firms can gain access to a broader range of financial instruments, including venture capital, large corporate partners on the equity side and banks and other financial institutions, on the debt side (Mann and Sager, 2007).

Moving to social tech start-ups, in the early growth phase, the imbalance between revenues and financing needs is further amplified because tend to achieve less revenues than high tech ones due to the internalization of relevant social costs (VanSandt, Sud and Marmé, 2009; Lumpkin, Moss, Gras, Kato, and Amezcua, 2013).

Considering the magnitude of the additional resources that are needed in this phase (Weber, Kröger, and Lambrich, 2014), social tech ventures look at commercial equity and debt as possible sources of financing. However, considering commercial equity, the same barriers already mentioned above continue to hinder their ability of accessing to traditional institutional solutions (Howard and Giddens, 2004; Miller, 2008; Wuttunee, Chicilo, Rothney and Gray, 2008). Considering debt, the main financing source is typically represented by bank loans, with whom social tech ventures do experience some significant challenges (Bank of England, 2003; OECD, 2015; SEUK, 2015). The first challenge is the lack of collateral (Jacockes and Price, 2010; Sunley and Pinch, 2012). There may be fewer assets available to use as loan security since social tech start-up are mainly equipped to generate social rather than financial value (Fraser, 2007). Indeed, there may be constraints related to the mission lock on how assets are disposed or the organizations itself might be reticent to use community assets as security (Sunley and Pinch, 2012). A second challenge is again related to the issue of information asymmetry, which jeopardizes the relationship with banks since they might not be acquainted with the peculiarities of social tech start-ups. This issue has different consequences that affect the social tech start-ups' ability to get a loan. First, banks apply to social ventures the same credit assessment of commercial ventures that does not recognize the social performance (Bank of England, 2003; Jacockes and Price, 2010); second, they charge the same financial costs that are often too high for SEs (Lyon and Baldock, 2014; SEUK, 2015); third, banks are usually scared by the lack of credit history and track record of this kind of ventures (Dees and Dolby, 1996; Smallbone, Evans, Ekanem and Butters, 2001). On the other hand, social tech start-ups themselves often do not have the proper knowledge of the capital market (Burkett, 2010; SEUK, 2015); thus, they are not ready and not willing to undertake costly due diligence processes and ongoing monitoring of the investment.

Identifying a potential market associated to these specific types of ventures, some mainstream financial intermediaries has decided to equip themselves to fulfil their needs. On the one hand, banks and financial institutions have made an attempt to tailor traditional financial products to social business organizations specificities. Some banks reserve some financial products to social business organizations. Other banks have set up a branch dedicated to this type of clients as well as cooperative banks, which usually have a strong relationship with their community (World Council of Credit Unions, 2012). 
On the other hand, new financial instruments have been designed. Beyond traditional sources of debt, a possible financing alternative is represented by Community Development Financial Institutions (CDFIs) (Jacockes and Price, 2010). They usually provide capital to market players that are underserved by commercial lenders using more flexible and patient conditions. The most common instrument is micro-loans (McWade, 2012). A business microloan is defined by the European Commission as any loan under EUR 25.000 aiming to support the development of self-employment and micro enterprises; it usually does not ask for assets as collaterals but implies other kinds of guarantees.

Finally, social tech ventures, as other SEs might experience some advantage in obtaining revenues from a specific source, i.e. national and local public authorities. Beyond grants, the support from public sector comes in the form of payments for services directly through commissioning or indirectly through subsidies given to specific categories of underprivileged individuals (Dees and Dolby, 1996). The aim of creating value for the community, and some related features such as the profit lock, makes social tech start-ups a favourite partner for governments. In addition, contracts with public sector might ensure the level of demand and financial support necessary to trigger the growth of the organization. Contracts with public sector may also have a signalling function: other capital providers might be reassured by the presence of another stable source of support (Dees and Dolby, 1996). In the domain of PPP, a new innovative instrument has emerged whose aim is to initially leverage on private capital to finance providers of social services, but shifting the risk of the partnership on public funding. The partnership is labelled as pay-for-success contracts and the financial instruments embedded in these contracts are the Social Impact Bonds (SIB) (Saltuk, El Idrissi, Bouri, Mudaliar, and Schiff 2014). A SIB can be defined as a hybrid tool with elements of either equity or debt, aimed at supporting preventive interventions through a pay for success contract (Azemati, Belinsky, Gillette, Liebman, Sellman and Wyse, 2013; Arena, Bengo, Calderini and Chiodo, 2016). In this model, the investors, through a financial intermediary, pay for a given social service which aims at achieving a social goal that is also a Government priority. If the offered service achieves the social goals defined, the Government remunerates the investors, otherwise, they lose their investment. This mechanism of "pay for success" aims to increase the number of available financial instruments and minimize the unfavourable risk and return relation, considering that the public entity remunerates the investors based on the success / failure of the initiative. Hence, these instruments change the risk allocation, shifting the risk from being entirely on the public administration that procures the service to being shared by the public entity, the social service providers, investors and intermediaries (Bengo and Calderini, 2016).

Lastly, the fourth stage is growth. A detailed analysis of this stage goes beyond the objectives of this paper, but is worthy of mentioning that companies in this phase face totally different challenges. Hopefully, companies here experience increasing volumes of sales and growing profitability. To finance growth, they could exploit both debt and equity (Hellmann and Puri, 2002). It is important to specify that there is still no evidence of SEs that were able to reach the same scale of large for profit high tech companies (European 
Commission, 2015; SEUK, 2015). Still, growing a SE does not primarily mean increasing the organization's size, but scaling social impact using different strategies beyond the increase in the level of revenues (Uvin, Pankaj and Brown 2000; Bradach, 2010; McPhedran Waitzer and Paul, 2011). In this stage, the pursue of a social mission and the relevance of mission lock requirements could likely hinder the option of public equity that we introduced for high tech start-ups (Howard and Giddens, 2004; Nicholls et al., 2015). Hence, commercial debt could end up to be the main possible source to support the scaling of a SE (Jacockes and Price, 2010). In terms of equity capital, many organizations have created social impact funds. They are ready-to-deploy pool of capital available to social ventures through a professionally managed, diversified fund. They are set apart from VP funds by the requirement of the return of the principal plus a certain rate of return. In addition, they have a ticket size that, although smaller than commercial venture capital funds, is still large if compared to the average dimension of social enterprises (Nicholls and Emerson, 2015). So, they are interested in grown/mature social tech startups because the transaction size in this stage is potentially bigger (GIIN, 2016: 21). Social impact fund investors are willing to undertake a more expensive due diligence and monitoring of the investment that, for instance, entails in site visiting to get a clearer idea of the social impact (Kho, Karamchandani and Katz, , 2012). Moreover, they usually provide free capacity building services to ensure that the entrepreneur will be able to successfully run his venture and realize the social impact that they want to achieve. For the same reason, they allow longer repayment times since they are aware that reaching the break-even point while selling goods and services aiming to achieve social impact requires more time and efforts (Nicholls and Paton, 2009). On the other hand, the requests of a financial return and of measuring both social and financial returns make social investors a source of funding that fits also the high-tech nature of social tech start-ups, unlike other sources typically pertaining to non-profit domain (e.g. grants, public contracts ...). Finally, both the actors and the financial instruments that characterize SII demand some ad hoc requirements that the social tech start-ups should respect. In general, SII ecosystem is enabled by a performance measurement infrastructure that aims to evaluate and monitor social impacts (Bugg-Levine and Emerson 2011). These requirements, that typically concentrate on measurable social impacts, can contribute to overcoming the problem of lack of understanding and potential mission drift supporting the achievement of social objectives, and limiting the problems of adverse selection, information asymmetry and moral hazard.

\section{Table 1: Outline of new financial barriers and new financial instruments}

The analysis of the financing needs occurring in different lifecycle stages of social tech start-ups has highlighted that these new ventures require, like high-tech start-ups, considerable initial funding for nourishing their activities and allowing scaling. However, in these ventures, the challenge of finding financial support is entangled with the need of conceiving strategies that do not aim to increase just the size of an organization, but its social impact using formal and informal networks, disseminating principles and practices, 
adding new services and changing the policy framework (Uvin et al., 2000; Bradach, 2010; McPhedran Waitzer and Paul, 2011).

The review of conventional funding sources has highlighted that the most common institutional solutions (such as grants, donations and state spending) are not enough to sustain the scaling of social tech start-ups. The above sources, in fact, are characterised by common drawbacks - i.e. they are generally tied up with specific projects, limited in their amount and time horizon. Moreover, commercial sources of external finance (e.g. commercial banks or venture capitalists) are typically less easily accessible to social tech start-ups since mainstream providers tend to not recognize the peculiarities of this emerging entrepreneurial model. These circumstances hinder the possibility of social tech start-ups to exploit these sources of financing to make long term investments (Brown, 2006) and poses significant challenges to the sustainability of their twofold nature - i.e. social and tech.

On the other hand, the new financial instruments described above are constituting and nurturing the family of social impact investing (SII). This term refers to investments that proactively pursue social and environmental goals (Nicholls and Emerson, 2015), putting at the forefront the creation of social impact. The field of SII is still emerging and the solutions created are far to be established and proved their effectiveness.

Therefore, though solutions to financially support social tech ventures have been provided by both the conventional funding sources and the emerging field of social impact investments, the analysis of their efficiency and effectiveness leaves relevant room for further investigation by scholars.

\section{A research agenda about the effectiveness of emerging solutions}

We analysed the financing instruments that are available to social tech start-ups, and we discussed the main problems that these ventures encounter in accessing to finance in the different phases of their lifecycle. The review of conventional funding sources has highlighted that the most common institutional solutions (such as grants, donations, social spending, debt capital from financial intermediaries, venture capital and private equity) present some major weaknesses that hamper their potential to sustain the scaling of social tech startups.

Considering the intentional pursuit of a social mission instead of profit maximization as the final goal of these organizations, we introduced social impact investing (SII) as an emerging solution that appears particularly promising to finance this type of social ventures. SII put at the forefront the creation of measurable social impact and look at the financial return as an additional benefit that could range from the repayment of the capital to a risk adjusted market rate return (Moore, Westley and Nicholls, 2012). Moreover, SII could represent an enormous market opportunity. GIIN, the global network of social impact investors, in its last survey (GIIN, 2016), reports that, in 2015158 impact investors at global level (mostly located in North 
America and Europe) financed 7.551 social impact investments for 15.2 billion dollars in total and the committed capital is expected to grow by $16 \%$ within the end of 2016. Since the first GIIN survey, respondents have increased from 25 to 158 and the capital committed has increased by 18\% from 2013 and 2015. Looking at pioneering markets in Europe, at the end of 2015 in UK $£ 1,5$ billion has been invested into regulated social organizations which show an annual growth of $20 \%$ (Robinson, 2016). Moreover, since 2010, when the first Social Impact Bond was launched, $£ 269$ million has been raised using this instrument. Players from the mainstream financial market are coming into the field, such as Deutsche Bank, Goldman Sachs and the European Investment Fund. The European Venture Philantrhophy association counts more than 210 members from over 29 countries and its survey (EVPA, 2014) reported a VP market of over $€ 5$ billion invested since about 8 years ago.

On the other hand, it is still a niche market if compared to socially responsible (SRI) investments based on a negative screeing: in 2014 SRI worldwide worth US\$ 14390 billion, while social impact investments US\$ 109 billion (GSIA, 2014).

On the other hand, as highlighted in the previous section, the field of SII is still emerging and the proposed instruments have not proved their sustainability and effectiveness yet, neither their role in financing social tech start-ups is globally acknowledged. Even, the UK SII ecosystem, which is usually pinpointed as the reference model, being somehow "more advanced" compared to other countries, has been recently criticised for its lack of transparency, unawareness of the actual financial needs of social innovators, and an excessive focus on the supply side. Also the SIB instrument, that is often considered paradigmatic of SII, has been heavily challenged in relationship to its possibility to redesign public procurement systems replacing existing contracts (Arena et al. 2016; McHugh, Sinclair, Roy, Huckfield and Donaldson, 2014).

Moving from these considerations, as follows, we outline a research agenda that deals with the potential of SII to support social tech start-ups in overcoming the barriers they experience in accessing to finance - i.e. how to prove SII sustainability and effectiveness.

The prior analysis has shown that many of these barriers are common to the different stages of the start-up lifecycle, being mainly related to the social mission of these organizations. Hence, as follows, we deepen the analysis of the barriers from a theoretical perspective, in order to draft a research agenda that could provide some insights about how to develop the frontier of SIl research.

To this aim, the first fundamental issue is related to achieving a better understanding of the size of the phenomenon at hand in terms of supply and demand of capital. This is an open issue because scholar and field experts in different countries have made some attempts to define the actual size of the market, but they ended up with raw estimations (G8 SII Taskforce, 2014) due to vagueness of SII boundaries, which still includes a heterogeneous array of instruments and actors. As a result, on the supply side, the data available 
about the volume of investment activities and the performance of the investments are still incomplete and difficult to compare (OECD, 2015).

Similarly, we lack robust evidence about the demand for this capital that would legitimize the existence of SII. Indeed, the quantification of the demand would require determining the number of social ventures there are in Europe (European Commission, 2015). However, available data generally concerns legally recognized social enterprises, which, in many countries, are far less than de-facto social ventures. Therefore, it is currently impossible to determine an aggregate figure at EU level. Just to give a flavor of this market, we can mention a few examples where more accurate data are available. In UK, one of the pioneering countries in the social entrepreneurship sector, there are about 284.000 SEs); in Italy, there are 1.600 Italian organizations formally registered as SEs registered according to several laws, while the estimation of organizations compliant with the EU definition of SE is 40.000; in France there are 315 société coopérative d'intérêt collectif (social cooperatives of public interest).

The previous considerations pave the way for the following research questions:

1. Which is the actual demand for socially oriented funding in different European countries?

2. Which is the potential demand for socially oriented funding in different European countries?

Once defined the size of the phenomenon, there are three main areas that appear crucial to explain its evolution: (1) the demand-supply matching; (2) the development of a proper accountability infrastructure; and (3) the development of the regulatory framework.

\subsection{Demand-supply matching}

Scholars in the SII field reported that one of the issues hindering the growth of SII market is the scarcity of investments-ready deals (Oleksiak, Nicholls, and Emerson, 2015). This is reasonable considering the characteristics of social ventures as described above: they usually origin from the nonprofit sector and they tend to give priority to the achievement of social impact rather than to commercial development. Therefore, they usually struggle to attract the resources that are necessary to sustain their generating impact activities.

This problem could be interestingly addressed relying on the resource-based view of the firm (RBV), as it states that firms gain a competitive advantage not only from the acquisition of resources, but also from their ability to combine and deploy these resources, creating core organizational "capabilities" (Wernerfelt, 1984). Accordingly, social tech start-ups may need to develop different and maybe more complex capabilities to manage the co-existence of conflicting institutional logics in their operational model and compensate for the lack of resources (Bacq, Kimberly and Eddleston, 2016). These "differential" capabilities might become a source of competitive advantage for them (Teece, Pisano and Shuen, 1997). Shedding light on which 
capabilities are the most relevant to the survival and growth of social tech start-ups and which are the most valuable to attract investments is a crucial element to enhance the supply-demand matching in the market. Therefore, we deem that the following research question is worthwhile to be deepened:

3. Which capabilities may help SEs to engage different types of financiers and in particular access to SII?

The centrality of this issue is further confirmed by an emerging trend, whereby social impact investors increasingly provide managerial training (beside financial support) to their investees (Oleksiak, Nicholls, and Emerson, 2015). The capacity building (including business planning, managerial, financial skills and HR management) provided by social impact investors might increase the social tech start-up's ability to develop the needed new hybrid capabilities or might force the enterprise to prioritize those aspects that have a positive impact on the economic performance, at the expense of the creation of social value. However, if and to what extent the capacity building services provided by the investors help the survival of these organizations has not been verified yet. This information may contribute to overcoming the issue of the limited supply of investment-ready organizations and boost the growth of the SII market.

Therefore, further investigation is needed to answer the following question:

4. Does the provision of non-financial services from investors enhance the survival of the social venture?

RBV can inform this research agenda also in relationship to a further aspect, the role of intangible assets. The most relevant resource for social ventures is probably a specific type of intangible that is defined as social capital (Evers, 2001; Mair and Martì, 2006; Dacin, Dacin and Matear, 2010). Social capital is based upon social networks and it refers to the values of trust, solidarity and willingness to cooperate that improve the efficiency of the society (Putnam, 1993; Knack and Keefer, 1997). These relational assets - that consist in affiliation to networks, members' support, embeddedness in the community - are a crucial source of competitive advantage for social ventures and they might represent a collateral for them, providing for physical assets. These intangibles are still unregistered, but it is commonly acknowledged that they have a value. Hence, research might contribute to overcome the challenge of lack of collateral in social tech startups by investigating the following question:

\section{How investors can account for the social capital in their decision making process?}

\subsection{The development of a proper accountability infrastructure}

The problem of ensuring accountability to stakeholders is obviously not new in literature, however, when social ventures are at stake, this issue becomes even more complex for two main reasons: the multistakeholders and multi-objectives approaches that characterizes these organizations and the lack of shared measurement system for social value (Rasche and Esser, 2006). 
Starting from the first characteristic, we argue that a significant theoretical lens is provided by the stakeholders theory that suggests that organizations are a "collection of various individual groups with different interests" (Laplume, Sonpar, and Litz, 2008) and that their decisions should consider the interest of all these groups (Donaldson and Lee, 1995). The hybrid nature of social ventures, where social aims and commercial models co-exist, affects also their relationships with the system of stakeholders. The social mission typically determines a closer relationship and involvement of certain stakeholder's caterogies (such as beneficiaries, local communities, other third sector organizations ...) that could imply some form of cocreation of the service and the development of participative governance models (Defourny and Nyssens, 2006; Ramírez, Bengo, Mereu, and Silva, 2011). On the other hand, the commercial model grounds on the ability of the organization of ensuring its economic sustainability, securing the necessary resources (hence interacting with investors, banks and potential funders).

The hybridity of social ventures implies that they should be able to build an accountability infrastructure where different groups of stakeholders are equally considered and provided with proper information (Pache and Santos, 2013). This could be easier when investors are social investors because they acknowledge the hybrid goal of SEs that is different from stockholder's value maximization (Nicholls and Emerson, 2015). To verify this potential benefit of SII, it is fundamental to detect the potential tensions between the investors and the other categories of stakeholder belonging to the social sector and exploring their dynamics. The insights from the stakeholder theory leads to the following questions:

6. Which are the potential tensions between financial investors and the other groups of SEs' stakeholders and how do they evolve?

Moving to the second matter, different authors recognize that the lack of a social impact measurement system with credible indicators and metrics is seriously limiting the development of social ventures (Nicholls, 2009). This lack worsens the information asymmetry problems (Akerlof, 1970), which according to the fundamentals of the agency theory are inherent to the relationship between an entrepreneur and an (impact) investor (Christensen, Wuebker, and Wustenhagen, 2000). The investor is regarded as the principal that delegates the production of a multiple outputs (money and impact) to an entrepreneur - the agent (Evans, 2013). Agency problems arise when the principal and the agent have different risk preferences, introducing, in addition to the asymmetry problem, the adverse selection problem. This situation is amplified when the entrepreneur exerts opportunistic behaviour and moral hazard in order to negotiate better financial terms with the venture capitalist (Amit et al., 1998). Different authors have recognised that performance measures provide a possible solution of these problems (Feltham and Xie, 1991; Lothe and Myrtveit, 2003).

Still measuring performance in a social venture is complex, because we have to measure the social impact of its activities on the society that is often not accompanied by a straightforward economic value. This value can be hardly captured with conventional accounting methods, that are conceived to monitor other types of 
performance (Schaltegger and Burritt, 2000). Traditionally, companies have focused mainly on financial performance measured through different recognised standards, and non-financial indicators able to provide companies early signals about the ability of the company to create economic value (i.e. value drivers, key performance indicators, balanced scorecards). However, when we move to the measurement of the impact on society, still now there is not a shared framework (Maas and Liket, 2010; Arena, Azzone and Bengo, 2015). This challenge is also amplified by the availability data and information. In order to build meaningful information about the impact of a social venture, various dimensions should be assessed (Elkington, 1999; Willard, 2002).

\section{Accordingly, the main research question is:}

\section{7. " How define an approach to measure the real social value?}

\section{To meet this problem is necessary also resolve these detailed questions:}

\section{What are the metrics?}

\section{We are loking for a standard measurement?}

\section{How to determine the standard measurement?}

\subsection{Development of the regulatory framework}

Finally, as highlighted in the previous analysis, the last crucial element for the development of social tech start-ups, is represented by the complex relationship with the public sector, that can play different roles in fostering the SII market and helping to overcome the barriers to the financing of social tech start-ups.

According to the state of the art literature, there are different forms of public governance models for SII. Governments act as regulators of the market if they approve legal acts and laws to govern this practice (Wells, 2012; Addis, 2015; Oleksiak et al., 2015). They can act as investors, if they provide capital directly to social business (Buzzacchi, Scellato and Ughetto, 2013) or indirectly investing in intermediaries (Castro-Spila, Luna and Unceta, 2016; Moore et al., 2012). Finally, they can play also the wider role of stewardship. As a steward, governments can create the facilitative infrastructure (Schwartz, Jones and Nicholls, 2015) that, in particular in the beginning phases, is necessary to ensure the social investees and investors readiness by establishing, for example, new specialized institutions, networks, capacity building programs (Wells, 2012; Glanzel and Scheuerle, 2015).

So far the government has been supportive of the SII market just in few pioneering countries, such as UK, US and Australia. From this perspective, it could be interesting to understand if it is possible to determine a contingency model to relate different policy approaches to the features of a specific area where SII are developing. Following the insights provided by the organizational contingency theory that contend that there is no one best way to lead, manage an organization or make decisions (Fiedler and Garcia, 1987; Tarter and 
Hoy, 1998), the contextual factors, that affect the intervention of the public sector in SII market and favor one specific role could be deepened, by exploring the following research questions:

11. To what extent should SII markets be regulated?

12. Given the characteristics of SII market to fulfil market failure, which kind of role can the government play?

Finally, it is worthy of mentioning that few countries in Europe have created a supporting legal environment for social tech start-ups. Many of them have adapted existing legal forms to account for their specific characteristics or created a new legal status. The lack of fiscal incentives to invest in these enterprises and the limit to profit distribution, however, makes this regulatory framework not coherent with the need of SII market. Just in France and UK, exemptions exist for investors into certain social ventures.

Therefore, we can raise some questions about the efficiency of the existing regulatory framework:

13. Are the existing regulatory framework for social venture supportive for their investment readiness?

Table 2: Research Agenda

\section{Conclusion}

The intuition that inspired this reflection is that when a high tech start-ups is added the "social mission", things may become simultaneously much harder or much simpler in terms of access to financial resources for growth. In other words, the coexixtence of business and social impact objectives in the entrepreneurial mission defines a complex and articulated systems of trade-offs that entail new barriers to the access to financial resources but also a set of new opportunities.

In order to give consistence to such intuition, this paper performs a critical analysis of the solutions that can be employed for financing social tech start-ups in the light of the social and technological trajectories that are currently shaping the broader social innovation ecosystem. More specifically this paper aimed to overcome the uncertainty as to how social tech start-ups can access to financialresources, what barriers do these organizations experience in looking for finance and what financial instruments are more suitable to to their financial needs, introducing the emerging practice of social impact investing (SII) and discussing its potentialities and limitations. Accordingly, we analyzed the main barriers that social tech start-ups encounter in accessing to financing in different lifecycle stages, highlighting how social tech start-ups do inherit many of the barriers that are typical of high-tech start-ups in the early phases of the lifecycle.

The analysis also showed that these barriers, in many cases, are further amplified by the hybrid nature of social tech start-ups that is reflected in their twofold aim of intentionally addressing a social need and safeguarding a financial return. Hybridity might be a source of confusion because these ventures fit neatly in 
neither the for profit nor the nonprofit categories (Bridgstock, Lettice, Özbilgin and Tatli, 2010) with a consequent impact on the volume and speed of the returns generated by a social tech start-up. These organizations aim to generate a blended value, where potentially lower financial returns are compensated by social returns. In addition, the time horizon needed to create social value is often higher if compared to pure financial value (Murphy and Coombes, 2009; VanSandt et al., 2009). On the other hand, hybridity can also help social tech start-ups to overcome some of the above barriers (Doherty et al., 2014) because hybrid organisations can rely on a wider range of sources of different nature, engaging both commercial financiers and those interested in supporting social issues (Chertok et al., 2008; McCarthy, 2012; Rago and Venturi, 2014) attracting both market and non-market sources of external finance (Teasdale, 2010).

In this landscape, we introduced social impact investing (SII) as a promising solution for answering to the financing needs of social tech start-ups. This emerging practice introduces a third dimension, in addition to risk and return, which should drive the decisions of investors: i.e. social impact. Intentionality in generating a social value, which can be quantified, sets SII apart from other forms of responsible investments. Considering that this issue has been largely unexplored in literature, even due to the novelty of the phenomenon from a business perspective, we formulated a research agenda, identifying directions for research and theory development in the field of SII using the case of social tech start-ups as paradigmatic of the broader problem of financing mechanisms for social innovation.

Our analysis shows that, despite SII has attracted high attention, there is little empirical evidence concerning this phenomenon and the dynamics related to its development and evolution remain largely undertheorized. One recent call has been put forward by Daggers and Nicholls (2016), that point out how the contribution to the understanding of this phenomenon of the academic literature is scarce, whilst there is need of research disentangling the multiple factors that (may) contribute to its rise and development. By drafting a research agenda (Table 2), we attempted to respond to this appeal, identifying some primary themes that academics should urgently address. The agenda encompasses three main issues, emerged as priorities from the literature analysis: the demand-supply matching, the development of a proper accountability infrastructure and the development of a regulative framework, with a clear role played by the public actor.

Therefore, the paper contributes to the field of SII by identifying those aspects that need to be further investigated to understand if and how SII responds to the financial needs of social ventures and how this field could develop. The originality of this work, within the SII literature, consist in assuming a demand-side perspective. Our believe is that, to be able to understand and anticipate the future trajectories of SII market, the link between the demand side and the supply side is crucial (and has been disregarded so far in academic works that mainly focused on the supply perspective). 
We would like to stress the relevance and the role of academic research as opposed to other kinds of research, to clarify the position academics might assume within the institutionalisation of the wider SII landscape. Why it is important that academics engage with this area of investigation?

The answer is very much depending on the nature of academic research and the maturity level of SII. In the emerging phase of the phenomenon, the existing literature on SII has been still dominated by practitioners and purely anecdotal evidence. However, after about seven years from the formulation of the concept, SII needs conceptual models able to interpret and explain its characteristics. Academic research should take on this role because it grounds on a pre-existing set of established theories and data sets that can ensure rigorous and sound results. We developed a research agenda about the efficiency of SII in financing socialtech start-ups to reinforce and narrow the call advanced by Daggers and Nicholls about the need of generating new empirical data and translating new knowledge into findings that can be used by both academics and practitioners. We believe that a broader knowledge base is necessary to ensure the growth and institutionalisation of SII. 


\section{References}

Achleitner, A., K., Spiess-Knafl, W., and Volk, S., 2014. The financing structure of social enterprises: conflicts and implications. International Journal of Entrepreneurial Venturing 6 (1), 85-99.

Addis, R., 2015. The roles of government and policy in social finance. In A. Nicholls, R. Paton, and J. Emerson (Eds.), Social Finance (pp. 383-459). Oxford, UK: Oxford University Press.

Akerlof, G., A., 1970. The market for lemons: Quality uncertainty and the market mechanism. Quarterly Journal of Economics 84, 488-500.

Allen, P., 2009. Restructuring the NHS again: supply side reform in recent English health care policy. Financial accountability \& management 25 (4), 373-389.

Alter, K., A., 2006. Social enterprise models and their mission and money relationships. In: A. Nicholls (Ed.), Social entrepreneurship: new models of sustainable social change (pp. 205-233). Oxford, UK: Oxford University Press.

Alvord, S., H., Brown, L., D., and Letts, C., W., 2004. Social entrepreneurship and societal transformation: an exploratory study. Journal of Applied Behavioral Science 40 (3), 260-282.

Amit, R., Brander, J., and Zott, C., 1998. Why do venture capital firms exist? Theory and Canadian evidence. Journal of Business Venturing 13, 441-466.

Arena, M., Azzone, G., and Bengo, I., 2015. Performance measurement for social enterprises. VOLUNTAS: International Journal of Voluntary and Nonprofit Organizations 26(2), 649-672.

Arena, M., Bengo, I., Calderini, M. and Chiodo, V., 2016. Social Impact Bonds: Blockbuster or Flash in a Pan? International Journal of Public Administration 39 (12), 927-939.

Austin, J., Stevenson, H., and Wei-Skillern, J., 2006. Social and Commercial Entrepreneurship: Same, Different, or Both?. Entrepreneurship Theory and Practice 30, 1-22.

Azemati, H., Belinsky, M., Gillette, R., Liebman, J., Sellman, A., and Wyse, A., 2013. Social impact bonds: lessons learned so far. Community Development Investment Review 1, 23-33.

Bacq, S., Kimberly, A., and Eddleston, A., 2016. Resource-Based View of Social Entrepreneurship: How Stewardship Culture Benefits Scale of Social Impact. Journal of Business Ethics, 1-23.

Bank of England, 2003. The Financing of Social Enterprises: A Special Report by the Bank of England. Bank of England, Domestic Finance Division. London, UK: Bank of England.

Battilana, J., and Dorado, S., 2010. Building sustainable hybrid organizations: The case of commercial microfinance organizations. Academy of Management Journal 53 (6), 1419-40.

Battilana, J., and Lee, M., 2014. Advancing research on hybrid organizing-Insights from the study of social enterprises. The Academy of Management Annals 8 (1), 397-441.

Battilana, J., Lee, M., Walker, J., and Dorsey, C., 2012. In search of the hybrid ideal. Stanford Social Innovation Review Summer 2012, 51-55.

Bengo, I., and Calderini, M., 2016. New development: Are social impact bonds (SIBs) viable in Italy? A new roadmap. Public Money \& Management 36 (4), 303-306.

Bengo, I., Arena, M., Azzone, G., and Calderini, M., 2016. Indicators and metrics for social business: a review of current approaches. Journal of Social Entrepreneurship 7 (1), 1-24.

Berger, A., N., and Udell, G., F., 1998. The economics of small business finance: The roles of private equity and debt markets in the financial growth cycle. Journal of Banking \& Finance 22 (6), 613-673.

Berger, A., N., and Udell, G., F., 2002. Small business credit availability and relationship lending: The importance of bank organisational structure. The economic journal 12 (Feb), F32-F53.

Bradach, J., 2010. Scaling impact: How to get $100 X$ the results with $2 X$ the organization. Stanford Social Innovation Review Summer, 27-28.

Bria, F., 2015. Growing a digital social innovation ecosystem for Europe. London: NESTA. Available at http://www.nesta.org.uk/publications/growing-digital-social-innovation-ecosystem- europe\#sthash.Wz3RBInL.dpuf

Bridgstock, R., Lettice, F., M., Özbilgin, M., F., and Tatli, A., 2010. Diversity management for innovation in social enterprises in the UK. Entrepreneurship \& Regional Development 22, 557-574.

Brown, J., 2006. Equity Finance for Social Enterprises. Social Enterprise Journal 2 (1), 73-81.

Bugg-Levine, A., Kogut, B., and Kulatilaka, N., 2012. A New Approach to Funding Social Enterprises - Unbundling societal benefits and financial returns can dramatically increase investment. Harvard Business Review 90 (1/2), 118123. 
Burkett, I., 2010. Financing social enterprise: understanding needs and realities. Foresters Community Finance and Social Traders. Available at www.foresters.org.au/knowledge-exchange/publications.

Buzzacchi, L., Scellato, G., Ughetto, E., 2013. The investment strategies of publicly sponsored venture capital funds. Journal of Banking and Finance 37 (3), 707-716.

Cajaiba-Santana, G., 2014. Social innovation: Moving the field forward. A conceptual framework. Technol. Forecast. Soc. Change 82, 42-51.

Carpenter, R., E., and Petersen, B., C., 2002. Capital market imperfections, high-tech investment, and new equity financing. The Economic Journal 112 (477), F54-F72.

Cassar, G., 2004. The financing of business start-ups. Journal of business venturing 19 (2), 261-283.

Castro Spila, J., Luna, A. and Unceta, A. (2016). Social Innovation Regime. An Exploratory Framework to measure Social Innovation. SIMPACT Working Paper, 2016 (1). Gelsenkirchen: Institute for Work and Technology.

Chertok, M., Hammoui, J., and Jamison, E., 2008. The funding gap. Stanford Social Innovation Review 26, 44-51.

Christensen, E., Wuebker, R. and Wüstenhagen, R., 2009. Of acting principals and principal agents: goal incongruence in the venture capitalist-entrepreneur relationship. Int. J. Entrepreneurship and Small Business 7 (3), 367-388.

Colombo, M., G., and Grilli, L., 2007. Funding gaps? Access to bank loans by high-tech start-ups. Small Business Economics 29 (1-2), 25-46.

Colombo, M., G., and Grilli, L., 2010. On growth drivers of high-tech start-ups: Exploring the role of founders' human capital and venture capital. Journal of Business Venturing 25 (6), 610-626.

Colombo, M., G., Franzoni, C., and Rossi-Lamastra, C., 2015. Internal social capital and the attraction of early contributions in crowdfunding. Entrepreneurship Theory and Practice 39 (1), 75-100.

Conathy, P., 2001. Homeopathic Finance - Equitable Capital for Social Enterprises. London, UK: New Economics Foundation.

Conti, A., Thursby, M., and Rothaermel, F., T., 2013. Show Me the Right Stuff: Signals for High-Tech Startups. Journal of Economics \& Management Strategy 22 (2), 341-364.

Cumming, D., J., Grilli, L., and Murtinu, S., 2014. Governmental and independent venture capital investments in Europe: a firm- level performance analysis. Journal of Corporate Finance, forthcoming.

Cusumano, N., and Spano, P., 2012. Financing the social enterprise. In: ISEDE-NET eds. Placing Value on Social Enterprise. Final Report of the WP5 Action. Development of innovative financial tools for social enterprise.

Dacin, P., A., Dacin, M., T. and Matear, M., 2010. Social entrepreneurship: why we don't need a new theory and how we move forward from here. Academy of Management Perspectives 24, 37-57.

Daggers, J., and Nicholls, A., 2016. The Landscape of Social Impact Investment Research: Trends and Opportunities. Oxford, UK: Saïd Business School.

Daly, S., 2011. Philanthropy as an Essentially Contested Concept. VOLUNTAS: International Journal of Voluntary and Nonprofit Organizations 23 (3), 535-557.

De Bettignies, J., E., 2008. Financing the entrepreneurial venture. Management Science 54 (1), 151-166.

Dees, J., G., 1998. Enterprising nonprofits: What do you do when traditional sources of funding fall short? Harvard Business Review January/February, 55-67.

Dees, J.G., and Dolby, N., 1996. Sources of Financing for New Nonprofit Ventures. Harvard Business Review.

Defourny, J., and Nyssens, M., 2006. Defining social enterprise. In M. Nyssens (Ed.), Social Enterprise: at the Crossroads of market, public policies and civil society (pp. 3-6). London \& New York: Routledge.

Desa, G., and Basu, S., 2013. Optimization or Bricolage? Overcoming Resource Constraints in Global Social Entrepreneurship. Strategic Entrepreneurship Journal 7 (1), 26-49.

Desa, G., and Kotha, S., 2006. Technology social ventures and innovation: understanding the innovation process at Benetech. In: F., Perrini (Ed.), New Social Entrepreneurship: What Awaits Social Entrepreneurial Ventures? (pp. 237259). Northampton, MA: Edward Elgar.

Doherty, B., Haugh, H., and Lyon, F., 2014. Social Enterprises as Hybrid Organizations: A Review and Research Agenda. International Journal of Management Reviews 16, 417-436.

Donaldson, T., and, Lee, P.E., 1995. The Stakeholder Theory of the Corporation: Concepts, Evidence, and Implications. Academy of Management Review 20 (1), 65-91.

Elkington, J., 2004. Enter the triple bottom line. The triple bottom line: Does it all add up 11 (12), 1-16.

Emerson, J., Freundlich, T., Fruchterman, J., Berlin, L., and Stevenson, K., 2007. Nothing Ventured, Nothing Gained:

Addressing the Critical Gaps in Risk-Taking Capital for Social Enterprise. Skoll Centre for Social Entrepreneurship.

European Commission, 2012a. Financing Social Impact. Funding Social Innovation in Europe - mapping the way

forward. Brussels: European Union. 
European Commission, 2012b. Strengthening Social Innovation in Europe. Brussels: European Union.

European Commission, 2015. A map of social enterprises and their ecosystems in Europe. Available at http://ec.europa.eu/social/main.jsp?langld=en\&catld=89\&newsld=2149\&furtherNews=yes\&preview=cHJldkVtcGxQ b3J0YWwhMjAxMjAyMTVwcmV2aWV3

Evans, M., 2013. Meeting the challenge of impact investing: how can contracting practices secure social impact without sacrificing performance? Journal of Sustainable Finance \& Investment 3 (2), 138-154.

Evers, A., 2001. The significance of social capital in multiple goal and resource structure of social enterprises. In C. Borzaga, and J. Defourny (Eds.), The Emergence of Social Enterprise. London, UK: Routledge.

European Venture Philathropy (EVPA). 2014. EVPA yearly survey 2013/2014 - European venture philanthropy and social investment Industry Survey 2013-2014. Brussel, BG: author.

Fedele, A., and Miniaci, R., 2010. Do Social Enterprises Finance Their Investments Differently from For-profit Firms? The Case of Social Residential Services in Italy. Journal of Social Entrepreneurship 1 (2), 174-189.

Feltham, G., A., and Xie., J., 1994. Performance Measure Congruity and Diversity in Multitask Principal/ Agent Relations. The Accounting Review 69 (3), 429-453.

Fiedler, F., E., and Garcia, J, E., 1987. New Approaches to Leadership, Cognitive Resources and Organizational Performance. New York, NY: John Wiley and Sons.

Fielden, S., L., Davidson, M., J., and Makin, P., J., 2000. Barriers encountered during micro and small business start-up in North-West England. Journal of Small Business and Enterprise Development 7 (4), 295-304.

Fischer, R., B., Wilsker, A., L., and Young, D., R., 2011. Exploring the revenue mix of nonprofit organizations: does it relate to publicness. Nonprofit and Voluntary Sector Quarterly 40 (4), 662-681.

Franz, H., W., Hochgerner, J., and Howaldt., J., 2012. Challenge Social Innovation: And Introduction. In: H. Franz, J. Hochgerner, J. Howaldt (Eds), Challenge Social Innovation, Potentials for Business, Social Entrepreneurship, Welfare and Civil Society (pp. 1-18). Berlin: Springer.

Fraser, S., 2007. Finance for Small and Medium-Sized Enterprises: Comparisons of Social Enterprises and Mainstream Businesses: A Report on the 2006 UK Survey of SME Finances Social Enterprise Booster Survey. Coventry, UK: Warwick Business School.

G8 Social Impact Investment [SII] Taskforce. 2014. Impact Investment: The Invisible Heart of Markets. London, UK. Gardner, C., A., Acharya, T., and Yach, D., 2007. Technological and social innovation: a unifying new paradigm for global health. Health Affairs 26 (4), 1052-1061.

GIIN and J.P. Morgan. 2016. Annual Impact Investor Survey. New York: J.P. Morgan and UK Impact Programme. Global Sustainable Investment Alliance (GSIA). 2014. 2014 Global Sustainable Investment Review. Bloomberg. Glaeser, E., L., and Shleifer, A., 2001. Not-for-profit entrepreneurs. Journal of Public Economics 81 (1), 99 - 115. Glänzel, G., and Scheuerle, T., 2015. Social Impact Investing in Germany: Current Impediments from Investors' and Social Entrepreneurs' Perspectives. VOLUNTAS: International Journal of Voluntary and Nonprofit Organizations, 131.

Gompers, P., and Lerner, J., 2001. The venture capital revolution. The Journal of Economic Perspectives 15 (2), $145-$ 168.

Graham, S., J., Merges, R., P., Samuelson, P., and Sichelman, T., 2009. High technology entrepreneurs and the patent system: Results of the 2008 Berkeley patent survey. Berkeley Technology Law Journal, 1255-1327.

Grimm, R., Fox, C., Baines, S., and Albertson, K., 2013. Social innovation, an answer to contemporary societal challenges? Locating the concept in theory and practice. Innovation: The European Journal of Social Science Research 26 (4), 436-455.

Hafenmayer, W., 2013. Venture philanthropy: approach, features, and challenges. Trusts \& Trustees 2013, 19 (6), 535541.

Haigh, N., L. and Hoffman, A., J., 2012. Hybrid Organizations: The Next Chapter of Sustainable Business. Organizational Dynamics 41 (2), 126-134.

Haigh, N., Walker, J., Bacq, S., and Kickul, J., 2015. Hybrid Organizations: Origins, Strategies, Impacts, and Implications. California Management Review, 57 (3).

Hall, R. E., and Woodward, S. E., 2010. The Burden of the Non diversifiable Risk of Entrepreneurship. American Economic Review 100 (3), 1163-94.

Harding, R., 2002. Plugging the knowledge gap: an international comparison of the role for policy in the venture capital market. Venture Capital: An International Journal of Entrepreneurial Finance 4 (1), 59-76.

Haugh, H., 2007. New Strategies for A Sustainable Society: The Growing Contribution of Social Entrepreneurship. Business Ethics Quarterly 17 (4), 743-749. 
Heins, E., Price, D., Pollock, A., M., Miller, E., Mohan, J., and Shaoul, J., 2010. A review of the evidence of third sector performance and its relevance for a universal comprehensive health system. Social Policy and Society 9 (04), 515526.

Hellmann, T., and Puri, M., 2002. Venture capital and the professionalization of start-up firms: Empirical evidence. The Journal of Finance 57 (1), 169-197.

Howard, L., and Giddens, M. (Eds.), 2004. Equity-like Capital for Social Ventures. London, UK: Bridges Community Ventures.

Howorth, C., A., 2001. Small firms' demand for finance: a research note. International Small Business Journal 19 (4), 78-87.

Hynes, B. 2009. Growing the social enterprise - issues and challenges. Social Enterprise Journal 5 (2), 114 - 125

Jacokes, J., and Pryce, J., 2010. The Life Cycle of Social Enterprise Financing. In Social Enterprise Alliance (Ed.), Succeeding at Social Enterprise (pp. 67-84). San Francisco, CA: Jossey-Bass.

Jay, J., 2013. Navigating paradox as a mechanism of change and innovation in hybrid organizations. Academy of Management Journal 56 (1), 137-159.

Jeng, L., A., and Wells, P., C., 2000. The determinants of venture capital funding: evidence across countries. Journal of corporate Finance 6 (3), 241-289.

Kamariah, I., Mir, H., S., and Umee, N., A., 2012. Technology social venture: A new genré of social entrepreneurship? Procedia - Social and Behavioral Sciences 40, $429-434$.

Karaphillis, G., Asimakos, S., Moore, S., 2010. Financing Social Economy organizations. Knowledge Mobilization Paper Series. Victoria: Canadian Social Economy Hub.

Kerlin, J. (2006). Social Enterprise in the United States and Europe: Understanding and learning from the differences. Voluntas 17 (3), 246-262.

Kickul, J., and Lyons, T., S., 2015. Financing Social Enterprises. Entrepreneurship Research Journal, Special Issue: Financing Social Enterprises.

Knack, S., and Keefer, P., 1997. Does Social Capital Have an Economic Payoff? A Cross-Country Investigation. Quarterly Journal of Economics 112 (4), 1251-1288.

Koh, H., Karamchandani, A, and Katz, R., 2012. From Blueprint to Scale: The Case for Philanthropy in Impact Investing. San Francesco, CA: Monitor Group.

Kortum, S., and Lerner, J., 2000. Assessing the contribution of venture capital to innovation. RAND journal of Economics 31 (4), 674-692.

Laplume, A., Sonpar, K., and, Litz, R., 2008. Stakeholder Theory: Reviewing a Theory That Moves Us. Journal of Management 34 (6), 1152-1189.

Leadbeater, C., 2007. Social enterprise and social innovation: Strategies for the next ten years. London, UK: Cabinet Office, Office of the Third Sector.

Lehner, O., M., 2013. Crowdfunding Social Ventures: A Model and Research Agenda. Venture Capital: An International Journal of Entrepreneurial Finance 15 (3), 289-311.

Lehner, O., M., and Nicholls, A., 2014. Social Finance and Crowdfunding for Social Enterprises: a Public-Private Scheme Providing Legitimacy and Leverage. Venture Capital: An International Journal of Entrepreneurial Finance 16 (3), 271 286.

Lothe, S., Myrtveit, I., and Trapani., T., 1999. Compensation Systems for Improving Environmental Performance. Business Strategy and the Environment 8 (6), 313-321.

Lumpkin, G., T., Moss, T.W., Gras, D.M., Kato, S. and Amezcua, A., S., 2013. Entrepreneurial processes in social contexts: how are they different, if at all? Small Business Economics 40 (3), 761-783.

Lyon, F., and Baldock, R., 2014. Financing social ventures and the demand for social investment. Working Paper. Third Sector Research Centre.

Maas, K. and Liket, K., 2011. Social impact measurement: a classification of methods. In: R. L. Burrit, S. Schaltegger, M. Bennett, T. Pohjola, M. Csutora (Eds.), Environmental management accounting and supply chain management (pp. 171-202). Dordrecht: Springer Netherlands.

Mair, J., and Martì, I., 2006. Social Entrepreneurship research: a source of explanation, prediction, and delight. Journal of World Business 41 (1), 36-44.

Mann, R., J., and Sager, T., W., 2007. Patents, venture capital, and software start-ups. Research Policy 36 (2), $193-208$.

Martin, M., 2011. Understanding the True Potential of Hybrid Financing Strategies for Social Entrepreneurs. Impact Economy Working Papers 2. Available at http://dx.doi.org/10.2139/ssrn.2209745. 
McCarthy, B., 2012. From fishing and factories to cultural tourism: the role of social entrepreneurs in the construction of a new institutional field. Entrepreneurship \& Regional Development 24, 259-282.

McHugh, N., Sinclair, S., Roy, M., Huckfield, L. and Donaldson, C., 2013. Social impact bonds: a wolf in sheep's clothing? Journal of Poverty and Social Justice 21 (3), 247-57.

McPhedran Waitzer, J, and Paul, R., 2011. Scaling social impact: when everybody contributes, everybody wins. Innovations 6 (2), 143-155.

McWade, W., 2012. The Role for Social Enterprises and Social Investors in the Development Struggle. Journal of Social Entrepreneurship 3 (1), 96-112.

Mendell, M., and Nogales, R., 2008. Social enterprises in OECD Member Countries: What are the financial streams? Concordia University, Montreal and EMES European Research Network.

Millard, J., and Carpenter, G., 2014. Digital technology in social innovation: a synopsis, a deliverable of the project: "The theoretical, empirical and policy foundations for building social innovation in Europe" (TEPSIE). European Commission - 7th Framework Programme. Brussels: European Commission, DG Research.

Miller, C., 2008. The Equity Capital Gap. Stanford Social Innovation Review Summer, 41-45.

Misuraca, G., Colombo, C., Kucsera, C., Carretero, S., Bacigalupo, M., and Radescu, R., 2015. Mapping and analysis of ICT-enabled Social Innovation initiatives promoting social investment through integrated approaches to the provision of social services. European Commission's Joint Research Centre, Institute for Prospective Technological Studies, EUR 2745 EN, JRC Science and Policy Report Series.

Moody, M., 2008. "Building a Culture": The Construction and Evolution of Venture Philanthropy as a New

Organizational Field. Nonprofit and Voluntary Sector Quarterly 37 (2), $324-352$.

Moore, M. L., Westley, F. R., and Nicholls, A., 2012. The Social Finance and Social Innovation Nexus. Journal of Social Entrepreneurship 3 (2), 115-32.

Murphy, P., J., and Coombes, S., M., 2009. A model of social entrepreneurial discovery. Journal of Business Ethics 87 , 325-336.

Nanda, R., and Rhodes-Kropf, M., 2013. Investment cycles and startup innovation. Journal of Financial Economics 110 (2), 403-418.

Nicholls, A., and Emerson, J., 2015. Social Finance: Capitalizing Social Impact. In A. Nicholls, R. Paton, J. Emerson (Eds.), Social Finance (pp. 207-249). Oxford, UK: Oxford University Press.

Nicholls, A. 2009. We do good things, don't we?: Blended value accounting in social entrepreneurship. Accounting Organizations and Society 34 (6-7), 755-769.

Nicholls, A. and Paton, R., 2009. Emerging resource flows for social entrepreneurship; theorizing social investment. In: British Academy of Management Annual Conference, 15-17 September 2009, Brighton, University of Brighton.

Nicholls, A., and Pharoah, C., 2008. The Landscape of Social Investment: a holistic topology of opportunities and challenges. Skoll Centre for Social Entrepreneurship Research Paper. Available at http://www.sbs.ox.ac.uk/skol.

Nicholls, A., Emerson, J., and Paton, R. (Eds.), 2015. Social Finance. Oxford University Press: Oxford.

Organisation for Economic Co-operation and Development [OECD], 2015. Social Impact Investment: Building the Evidence Base. Paris, FR: OECD Publishing.

Oleksiak, A., Nicholls, A., and Emerson, J., 2015. Impact investing: a market in evolution. In A. Nicholls, R. Paton, J. Emerson (Eds.), Social Finance (pp. 207-249). Oxford, UK: Oxford University Press.

Ou, C., and Haynes, G., W., 2006. Acquisition of additional equity capital by small firms-findings from the national survey of small business finances. Small Business Economics 27 (2-3), 157-168.

Pache, A., and Santos, F., 2013. Inside the hybrid organization: Selective coupling as a response to competing institutional logics. Academy of Management Journal 56 (4), 972 - 1001.

Papadimitriou, S., and Mourdoukoutas, P., 2002. Bridging the start-up equity financing gap: three policy models. European Business Review 14 (2), 104-110.

Paton, R., 2003. Managing and Measuring Social Enterprises. London, UK: Sage Publications.

Phillips, R., G., 2002. Technology business incubators: how effective as technology transfer mechanisms? Technology in Society 24 (3), 299-316.

Plotnieks, D., 2014. Mechanisms Fostering Social Entrepreneurship as Potential Instruments for Economic Development: The Eastern Partnership Perspective. Baltic Journal of European Studies 4 (2), 34-49.

Pot, F., and Vaas, F., 2008. Social innovation, the new challenge for Europe. International Journal of Productivity and Performance Management 57 (6), 468-473.

Putnam, R., D., 1993. Making Democracy Work. Civic traditions in modern Italy. Princeton NJ: Princeton University Press. 
Rago, S., and Venturi, P., 2014. Hybridization as Systemic Innovation: Italian Social Enterprise on the Move. Paper presented at VI ed. of "International Social Innovation Research Conference - ISIRC". Northampton, UK,

Rahman R., and Smith, L., 2014. Social Innovation Mapping: Social Entrepreneurs Changing Lives Through ICT. Ashoka \& Intel.

Ramírez, M. C., Bengo, I., Mereu, R., and Silva, J. C., 2011. Participative methodology for local development: the contribution of engineers without borders from Italy and Colombia: towards the improvement of water quality in vulnerable communities. Systemic Practice and Action Research 24(1), 45-66

Rasche, A., and Esser, D.E., 2006. From Stakeholder Management to Stakeholder Accountability. Journal of Business Ethics 65 (3), 251-67.

Ridley-Duff, R., J., and Bull, M., 2011. Understanding Social Enterprise: Theory and Practice. London, UK: Sage Publications.

Robinson, M. 2016. The size and composition of social investment in the UK. London, UK: Big Society Capital.

Saltuk, Y., Idrissi, A., Bouri, A., Mudaliar, A., and Schiff, H., 2014. Spotlight on the market: The impact investor survey. London: Global Social Finance, JP Morgan and the Global Impact Investing Network.

Scellato, G., 2007. Patents, firm size and financial constraints: An empirical analysis for a panel of Italian manufacturing companies. Cambridge Journal of Economics 31, 55-76.

Schaltegger, S. and Burritt, R., L., 2000. Contemporary Environmental Accounting - Issues, Concepts and Practice. Sheffield: Greenleaf Publishing.

Schwartz, R., Jones, C., and Nicholls, A., 2015. Building the Social Finance infrastructure. In A. Nicholls, R. Paton, and J. Emerson (Eds.), Social Finance (pp. 488-517). Oxford, UK: Oxford University Press.

Seddon, F. A., Hazenberg, R., and Denny, S., 2013. What are the barriers to investing in social enterprises? An investigation into the attitudes and experiences of social entrepreneurs in the United Kingdom. Paper presented at 4th EMES European Research Network International Research Conference on Social Enterprise. University of Liege, Belgium, 01-04 July 2013.

Shane, S., and Cable, D., 2002. Network ties, reputation, and the financing of new ventures. Management Science 48 (3), 364-381.

Smallbone, D., Evans, M., Ekanem, I., and Butters, S., 2001. Researching Social Enterprise. Final Report to the Small Business service Centre for Enterprise and Economic Development Research. London, UK: Middlesex University.

Smith, G., and Teasdale, S., 2012. Associative democracy and the social economy: exploring the regulatory challenge. Economy and Society 41, 151-176.

Social Enterprise UK [SEUK], 2015. State of Social Enterprise Survey 2015. London, UK: Author.

Spiess-Knafl, W., and Achleitner, A., K., 2012. Financing of Social Entrepreneurship. In C. K., Volkmann, K. O. Tokarski, and K. Ernst (Eds.). Social Entrepreneurship and social business (pp. 157-173). Wiesbaden, Germany: Gabler.

Sunley, P., and Pinch, S., 2012. Financing social enterprise: social bricolage or evolutionary entrepreneurialism? Social Enterprise Journal 8 (2), 108-122.

Tarter, C., J., and Wayne, K., H., 1998. Toward a contingency theory of decision making. Journal of Educational Administration, 36 (3), $212-228$.

Teasdale, S., 2010. Explaining the multifaceted nature of social enterprise: impression management as (social) entrepreneurial behaviour. Voluntary Sector Review 1, 271-292.

Teece, D., J., Pisano, G., and Shuen, A., 1997. Dynamic capabilities and strategic management. Strategic Management Journal 18 (7), 509-533.

Uvin, P., Pankaj S., J., and Brown, D., L., 2000. Think Large and Act Small: Towards a New Paradigm for NGO Scaling Up. World Development 28, 8.

VanSandt, C., Sud, M., and Marmé, C., 2009. Enabling the original intent: catalysts for social entrepreneurship. Journal of Business Ethics 90, 419-428.

Venturelli, V., and Gualandri, E., 2009. The determinants of equity needs: size, youth or innovation? Journal of Small Business and Enterprise Development 16 (4), 599-614.

Venturi, P., and Zandonai F. (Eds.), 2012. L'impresa sociale in Italia. Pluralità dei modelli e contributo alla ripresa, Rapporto Iris Network. Milano, IT: Altreconomia.

Venturi, P., and Zandonai, F. (Eds.), 2014. L'impresa sociale in Italia. Identità e sviluppo in un quadro di riforma, Rapporto Iris Network. Available at http://www.irisnetwork.it/wp-content/uploads/2014/12/Rapporto-IrisNetwork.pdf.

Verheul, I., and Thurik, R., 2001. Start-up capital:"does gender matter?". Small business economics 16 (4), $329-346$. 
Von Zedtwitz, M., and Grimaldi, R., 2006. Are Service Profiles Incubator-Specific? Results from an Empirical Investigation in Italy. The Journal of Technology Transfer 31 (4), 459-468

Watson, R., and Wilson, N., 2002. Small and medium size enterprise financing: A note on some of the empirical implications of a pecking order. Journal of Business Finance \& Accounting 29 (3-4), 557-578.

Weber, C, Kröger, A., and Lambrich, K., 2014. A theoretical model for understanding the scalability of social impact. In P. H. Phan, J. Kickul, S. Bacq and M. Nordqvist (Eds.), Theory and empirical research in social entrepreneurship (pp. 112-153). Cheltenham: Edward Elgar.

Wells, P., 2012. Understanding Social Investment Policy: Evidence from the Evaluation of Futurebuilders in England. Voluntary Sector Review 3(2), 157-77.

Wernerfelt, B., 1984. A Resource-Based View of the Firm. Strategic Management Journal 5 (2), 171-180.

Willard, B., 2002. The sustainability advantage: Seven business case benefits of a triple bottom line. Gabriola: New Society Publishers.

Wilson, F., and Post, E., J., 2013. Business models for people, planet \& profits: exploring the phenomena of social business, a market-based approach to social value creation. Small Business Economics 40 (3), 715-737.

World Council of Credit Unions, 2012. Statistical Report. Madison, WI: World Council of Credit Unions.

Wuttunee, W., Chicilo, M., Rothney, R., and Gray, L., 2008. Financing Social Enterprise. An Enterprise Perspective. Canada: Northern Ontario, Manitoba, and Saskatchewan Regional Node of the Social Economy Suite. Available at: http://usaskstudies.coop/documents/social-economy-reports-and-newsltrs/Financing\%20Soc\%20Enterprisepart\%202.pdf. 
Table 1: Outline of new financial barriers and new financial instruments

\begin{tabular}{|c|c|c|c|}
\hline Stage & $\begin{array}{c}\text { Financial } \\
\text { Needs }\end{array}$ & Barriers & Type of capital \\
\hline Seed & Low & $\begin{array}{ll}\text { - } & \text { High risk } \\
\text { - } & \text { Unfavorable risk/return relation } \\
\text { - } & \text { Threat of mission drift } \\
\text { - } & \text { Legal form } \\
\text { - } & \text { Lack of managerial skills }\end{array}$ & $\begin{array}{ll}\text { - } & \text { Grants from charities } \\
\text { - } & \text { Grants from corporation } \\
\text { - } & \text { Grants from government } \\
\text { - } & \text { agencies } \\
\text { - } & \text { Retail (crowdfunding; peer to } \\
\text { - } & \text { Busineer lending) } \\
\end{array}$ \\
\hline Start-up & High & $\begin{array}{l}\text { - Information asymmetry } \\
\text { - } \quad \text { Performance measurement and } \\
\text { monitoring } \\
\text { - } \quad \text { Moral Hazard } \\
\text { - Legal form }\end{array}$ & $\begin{array}{ll}\text { - } & \text { Equity (crowdfunding) } \\
\text { - } & \text { Hybrid financing forms } \\
\text { - } & \text { Patient Capital } \\
\text { - } & \text { Mezzanine financing } \\
\text { - } & \text { Venture Philanthropy }\end{array}$ \\
\hline Early Growth & Very high & $\begin{array}{ll}\text { - } & \text { Information asymmetry } \\
\text { - } & \text { Lack of collateral } \\
\text { - } & \text { Lack of financial skills } \\
\text { - } & \text { Fear of failure }\end{array}$ & $\begin{array}{ll} & \text { Public Procurement } \\
\text { - } & \text { Social Impact Bonds } \\
\text { - } & \text { Microfinance } \\
\text { - } & \text { Term Debt with flex features } \\
& \text { (social banks) } \\
\text { - } & \text { Subordinate Debt } \\
\end{array}$ \\
\hline Growth & Medium & $\begin{array}{ll}\text { - } & \text { Size } \\
\text { - } & \text { Mission lock requirements }\end{array}$ & $\begin{array}{ll}\text { - } & \text { Commercial Debt } \\
\text { - } & \text { Equity (Social Impact Fund) }\end{array}$ \\
\hline
\end{tabular}


Table 2: Research Agenda

\begin{tabular}{|c|c|c|c|}
\hline $\begin{array}{c}\text { Area of } \\
\text { investigation }\end{array}$ & Barriers & Reference theory & Research questions \\
\hline \multirow[t]{3}{*}{$\begin{array}{l}\text { Demand and supply } \\
\text { matching }\end{array}$} & $\begin{array}{l}\text { Further difficulties in } \\
\text { obtaining resources }\end{array}$ & \multirow[t]{3}{*}{ Resource Based view } & $\begin{array}{l}\text { Which capabilities may help SEs to } \\
\text { engage different types of financiers? }\end{array}$ \\
\hline & $\begin{array}{l}\text { Lack of managerial and } \\
\text { financial skills }\end{array}$ & & $\begin{array}{l}\text { Does the provision of non-financial } \\
\text { services from investors enhance the } \\
\text { survival of the social venture? }\end{array}$ \\
\hline & Lack of collaterals & & $\begin{array}{l}\text { How investors can account for the social } \\
\text { capital in their decision making process? }\end{array}$ \\
\hline \multirow[t]{2}{*}{ Accountability issue } & $\begin{array}{l}\text { Need of balance the } \\
\text { "social" stakeholders and } \\
\text { "economic" stakeholders' } \\
\text { interests }\end{array}$ & Stakeholder Theory & $\begin{array}{l}\text { Which are the potential tensions } \\
\text { between financial investors and the other } \\
\text { groups of SEs' stakeholder? }\end{array}$ \\
\hline & $\begin{array}{l}\text { Lack of measurement } \\
\text { system for social value }\end{array}$ & Agency theory & $\begin{array}{l}\text { How we measure the real social value? } \\
\text { What are the metrics? } \\
\text { Do we need a standard measurement? } \\
\text { How to determine the standard } \\
\text { measurement? }\end{array}$ \\
\hline Regulatory framework & $\begin{array}{l}\text { Lack of public sector } \\
\text { intervention }\end{array}$ & Contingency Theory & $\begin{array}{l}\text { To what extent should SII markets be } \\
\text { regulated? } \\
\text { Given the characteristics of SII market to } \\
\text { fulfil market failure, which kind of role can } \\
\text { the government play? }\end{array}$ \\
\hline
\end{tabular}

